\title{
Second Generation Biodiesel Production from Upgrading of Palm-Based Bio-Oil: Technology Study through Process Simulation
}

\author{
Maharani Dewi Solikhah ${ }^{1 *}$, Hanafi Prida Putra1, Adi Prismantoko1, \\ Agus Kismanto ${ }^{1}$, Galuh Wirama Murti ${ }^{1}$, Tetsuya Araki ${ }^{2}$, Hiroshi Nabetani ${ }^{2,3}$ \\ ${ }^{1}$ Agency for the Assessment and Application of Technology, \\ South Tangerang 15314, Indonesia. \\ ${ }^{2}$ The University of Tokyo, Tokyo 113-8657, Japan. \\ ${ }^{3}$ National Food Research Institute, Ibaraki 305-8642, Japan.
}

\begin{abstract}
Biodiesel has become favorable fuel for diesel fuel substitute to overcome the limited fossil fuel resources while facing the increasing of energy consumption. However, the use of FAME biodiesel is currently limited to mixing up to $30 \%$. Therefore, it is necessary to consider other fuels as an alternative to diesel oil. One of them is by developing second generation biodiesel, which produced from the upgrading process of bio-oil as a result of pyrolysis. Bio-oil can be upgraded to fuel with range naphtha through two main processes that consists of hydro-processing and catalytic cracking. Techno-economic studies on bio-oil production from oil palm biomass have been studied but the techno-economic studies up to upgraded bio-oil have not included. Before a techno-economic study was carried out, it was necessary to select the process technology route of upgrading bio-oil. Therefore, it is required to conduct study of industry and the comparison of second generation biodiesel production technology from the upgrading of oil palm-based bio-oil to obtain an optimum process flow diagram. Process simulations were conducted using ChemCad software so that the mass balance and ratio of energy consumption was obtained. This work estimated the bio-fuel produced from palm residues collected from 19 units of a 60 tons hour ${ }^{-1}$ palm oil mill. The bio-oil input is 70.35 tons hours ${ }^{-1}$ with upgrading oil yield of $32.21 \%$. Energy yield of this model is $35.7 \%$ while required $76.5 \mathrm{MMJ}^{-1}$ hour $^{-1}$ of the energy. Energy required for this process can be provided by an integrated fuel upgrading facilities that connected with the palm bio-oil production plant could provide self-sustainable production facilities.
\end{abstract}

Keywords: catalytic cracking, diesel fuel substitute, hydro-processing, pyrolisis

\footnotetext{
${ }^{*}$ Corresponding author:

Center for Fuel Technology and Engineering Design, Agency for the Assessment and Application of Technology Building 480 ${ }^{\text {th }}$, Puspiptek Area, Serpong, South Tangerang 15314, Indonesia.

Email: maharani.dewi@bppt.go.id
} 


\section{INTRODUCTION}

Biodiesel or fatty acid methyl ester (FAME) has become favorable fuel for diesel fuel substitute to overcome the limited fossil fuel resources while facing the increasing of energy consumption. As a renewable fuel, it can be produced from vegetable oil such as palm oil, soybean oil, or rapeseed oil. In accordance with united nations sustainable development goals (UN SDGs), implementation of biodiesel will promote the achievement of goal 7 to increase substantially the share of renewable energy in the global energy mix (UN 2015). Implementation of biodiesel in Indonesia has become progressive by applying mandatory of B20 since January 2016 (ESDM 2015). The biodiesel mixing obligation will be increased to $30 \%$ (B30) in January 2020. Biodiesel used in mixing is currently carried out by using $1^{\text {st }}$ generation biodiesel or FAME. The higher blending of FAME biodiesel faces several obstacles because some materials in the engine are not compatible with methyl esters and need to be adjusted or replaced. Another problems arised from the power reduction in using biodiesel mixed more than $30 \%$, because of its high oxygen content.

Therefore, it is important to consider other alternative fuels as mixtures in diesel oil. One of them is by developing $2^{\text {nd }}$ generation biodiesel which derived from upgrading of bio-oil or pyrolysis oil. The definition of $2^{\text {nd }}$ generation biodiesel production technology is found in Figure 1. $2^{\text {nd }}$ generation biodiesel has the opportunity to be used as a mixture of diesel oil because its characteristic is similar to diesel oil compared to FAME biodiesel. This is because the composition of second generation biodiesel consists of hydrocarbons with lower oxygen levels (Fan et al. 2017).
Second generation biodiesel is produced from woody biomass or lignocellulosic biomass that can be obtained from plantation waste, for example oil palm plantations and agricultural waste, such as rice husk (Surjosatyo et al. 2017) and sugarcane baggase (Pradana et al. 2019). As the largest palm oil producer in the world, Indonesia has an enormous potential of palm biomass which can be either palm shells, fibers, empty fruit bunches (EFB) and palm fronds. With productivity of 4.4 tons hectare ${ }^{-1}$ year $^{-1}$ of EFB (Abnisa et al. 2013). Indonesia can produce 46 million tons of EFB from having more than 10.5 million hectares of oil palm plantation (BPS 2018).

Pyrolysis technology has also been developed by various institutions in the world, both laboratory scale and industrial scale. The commercially produced pyrolysis plant is Empyro in the Netherlands, which uses technology from biomass technology group (BTG) of the Netherlands. This plant is capable of producing bio-oil with a capacity of 3.2 tons hour $^{-1}$ from 5 tons hour ${ }^{-1}$ of wood chips (BTG 2017). Bio-oil produced is used in electric generators as a substitute for fuel oil and cannot be used in diesel vehicles.

To be used in diesel engines, bio-oil needs to be improved in quality through the upgrading process. Bio-oil can be upgraded into fuel in naphtha range through two main processes, which is hydro-processing and catalytic cracking (Shemfe 2015). To understand the feasibility of this technology, a techno-economic analysis is required. Several techno-economic studies on the production of bio-oil from palm biomass have been carried out, however the techno-economic studies of the extended process to produce upgraded palm based bio-oil have not included. In order to conduct techno-economy study, a process evaluation is required. 
Conventional biodiesel processing Upgrading biodiesel quality

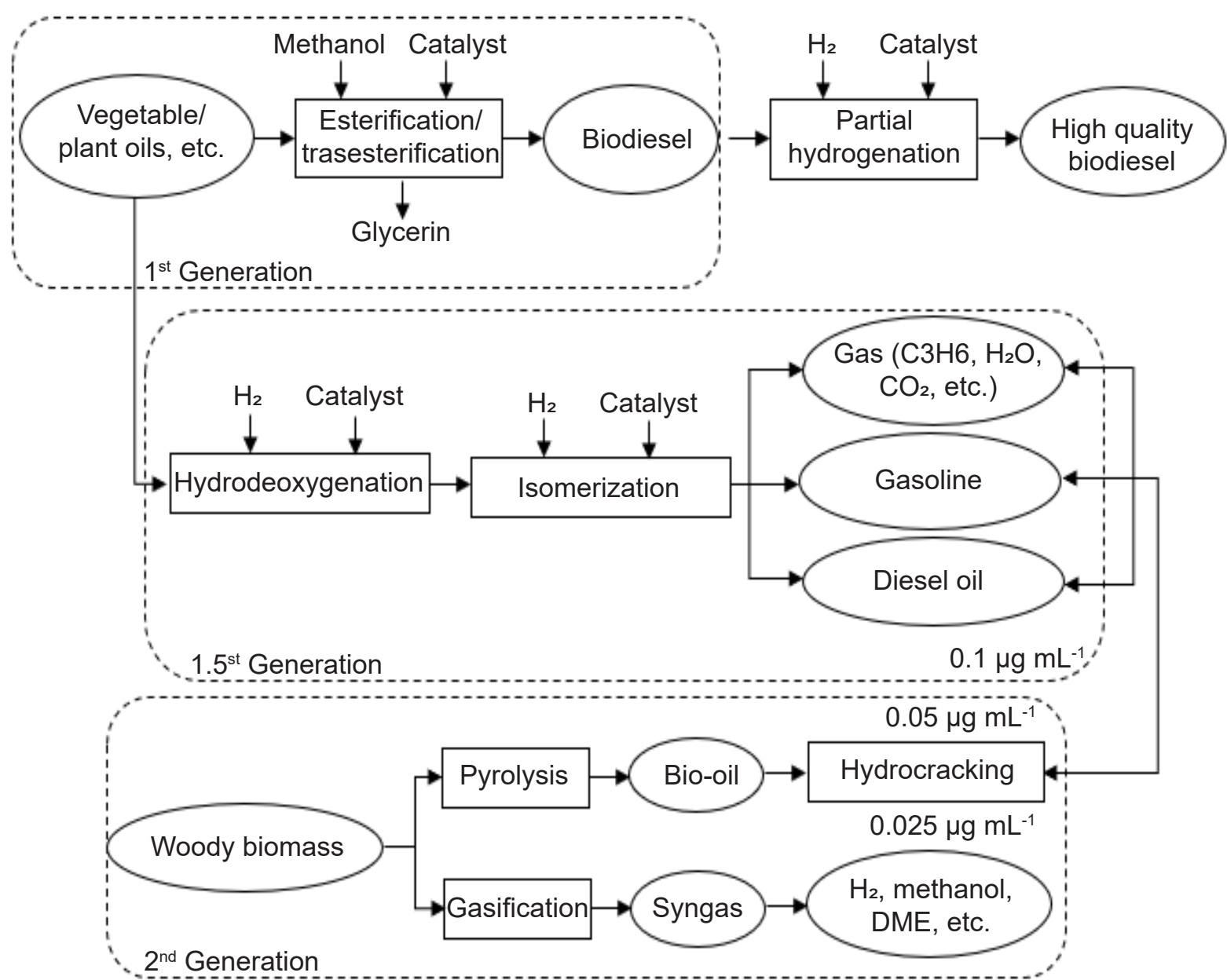

Figure 1 Process for production of $2^{\text {nd }}$ generation biodiesel.

Therefor, this study is conducted to evaluate the process of upgrading bio-oil from palm based biomass through simulation process.

\section{MATERIALS AND METHODS}

\section{Feedstocks}

The feed-stocks of bio-oil in this study is using palm empty fruit bunch produced from palm oil mill. EFB was chopped and powdered into 16-30 mesh with moisture content of $12.73 \%$ mass according to previous study (Solikhah et al. 2018). Pyrolysis process produced bio-oil with heating value of $26.49 \mathrm{MJ} \mathrm{kg}^{-1}$ and water content of $11.54 \%$ mass. Water content in bio-oil was analyzed using Karl Fisher KF200
(Mitsubishi Chemical Analytech Co.,Ltd., Kanagawa, Japan). The heating value of bio-oil was measured using automatic calorimeter AC500 (Leco Corp., Saint Joseph, USA).

\section{Model of Pyrolysis Oil using Chemcad}

The bio-oil from EFB was modeled using a mixture of compounds from the chemical analysis and previous studies (Solikhah et al. 2018). The compounds was selected from database of Chemcad 6.5.3 (Chemstations Inc. USA). Other compounds that not available in the database was created into the database using molecular weight and density of the component. The mass fraction of each compound was determined by compositinal 
analysis and data provided by Jones et al. (2013). Table 1 presents the selected model compounds of the water-soluble phase of bio-oil. Meanwhile Table 2 presents the selected model compounds of the water-insoluble phase of bio-oil.

Hydrotreating of bio-oil occurs in three stages and the reactions are very complex. Table 3 shows the mixture of intermediate model compounds used to represent the hydrotreated oil from stage 1 (stabilizer) and stage 2 (first reactor). While Table 4 shows the compounds of upgrading oil from stage 3 (second reactor).

\section{Process Design}

The overview process flow diagram for the conversion of bio-oil from into fuel is presented at Figure 2. The plant used in this model processes 70.35 MT hour ${ }^{-1}$ of palm based bio-oil for comparison

Table 1 Model compounds water soluble used to represent bio-oil

\begin{tabular}{ll}
\hline Group compound & Model compound \\
\hline Acids & Acetic acid \\
Alcohols & 2-furanmethanol \\
Ketones & 2-propanone, 1-hydroxy- \\
Aldehydes & 2-furancarboxaldehyde \\
Phenolic & Phenol \\
Benzene & Benzene, 1,2,3-trimethoxy- \\
Guaiacols & Isoeugenol \\
Low MW sugars & Levoglucosan \\
High MW sugars & Cellobiose \\
\hline
\end{tabular}

Table 2 Model compounds water insoluble used to represent bio-oil

\begin{tabular}{ll}
\hline Group compound & Model compound \\
\hline Low MW lignin & $\begin{array}{l}\text { Dimethoxy stilbene, } \\
\text { dibenzofuran }\end{array}$ \\
Exived compounds & Dehydroabietic acid \\
High MW lignin & $\begin{array}{l}\text { Oligomeric compounds, } \\
\text { phenylcoumaran com- } \\
\text { derived compounds }\end{array}$ \\
Nitrogen compounds & $2,4,6$-trimethylpyridine \\
Sulfur compounds & Dibenzothiophene \\
\hline
\end{tabular}

with the work of Jones et al. (2013). This capacity can be fulfilled by 19 palm oil mills in capacity of 60 ton hour ${ }^{-1}$ of palm fresh fruit bunch, by using a model developed by Peryoga et al. (2014) as well Garcia-Nunez et al. (2016).

Upgrading consists of two separate reactions: hydrotreating and hydrocracking (Jones 2013). The removal of oxygen content of pyrolysis oil can be conducted using

Table 3 Model compounds representing intermediates hydrotreating products

\begin{tabular}{ll}
\hline Intermediates from & Model compound \\
\hline Small acids & n-butyric acid \\
$\begin{array}{l}\text { Small aldehydes, alcohols, } \\
\text { ketons }\end{array}$ & 1,2-propanediol \\
Sugars & Glucose, sorbitol \\
Extractives & HT dehydroabietic acid \\
Low MW lignin & Pinosylvin \\
derived compounds & \\
High MW lignin & Indene \\
derived compounds & 4-methylphenanthrene \\
\hline
\end{tabular}

Table 4 Upgraded oil model compounds

\begin{tabular}{|c|c|}
\hline Group compound & Model compound \\
\hline Normal paraffins & Hexane, dodecane, pentane \\
\hline Iso-paraffins & $\begin{array}{l}\text { 3-methylhexane, 4-methyl- } \\
\text { nonane }\end{array}$ \\
\hline Cyclopentanes & $\begin{array}{l}\text { Cyclopentane, ethyl 1-meth- } \\
\text { yl-1-ethylcyclopentane }\end{array}$ \\
\hline Cyclohexanes & $\begin{array}{l}\text { Cyclohexane, butyl 1,1-bicy- } \\
\text { clohexyl }\end{array}$ \\
\hline Cyclo C7+ & 1,3-dimethyladamantane \\
\hline Aromatics & $\begin{array}{l}\text { o-xylene, benzene, 1-ethe- } \\
\text { nyl-4-ethyl }\end{array}$ \\
\hline Heavies & 4-methylphenanthrene pyrene \\
\hline Diphenyl & 1,2-diphenylethane \\
\hline Indanes and indenes & $\begin{array}{l}\text { Indane } 1 \mathrm{H} \text {-indene, } \\
\text { 1,2,3-trimethyl- }\end{array}$ \\
\hline $1,2,3,4$ naphtalenes & $\begin{array}{l}\text { 1-nHexyl-1,2,3,4-tetrahy- } \\
\text { dronaphthalene }\end{array}$ \\
\hline Naphthalenes & Naphthalene, 2,7-dimethyl \\
\hline PNAs & Naphthalene, 1-phenyl- \\
\hline Oxygenates & $\begin{array}{l}\text { 5-methyl-2-(1-methylethyl) } \\
\text { phenol }\end{array}$ \\
\hline Nitrogen compounds & 2,4,6-trimethylpyridine \\
\hline Sulfur compounds & Dibenzothiophene \\
\hline
\end{tabular}




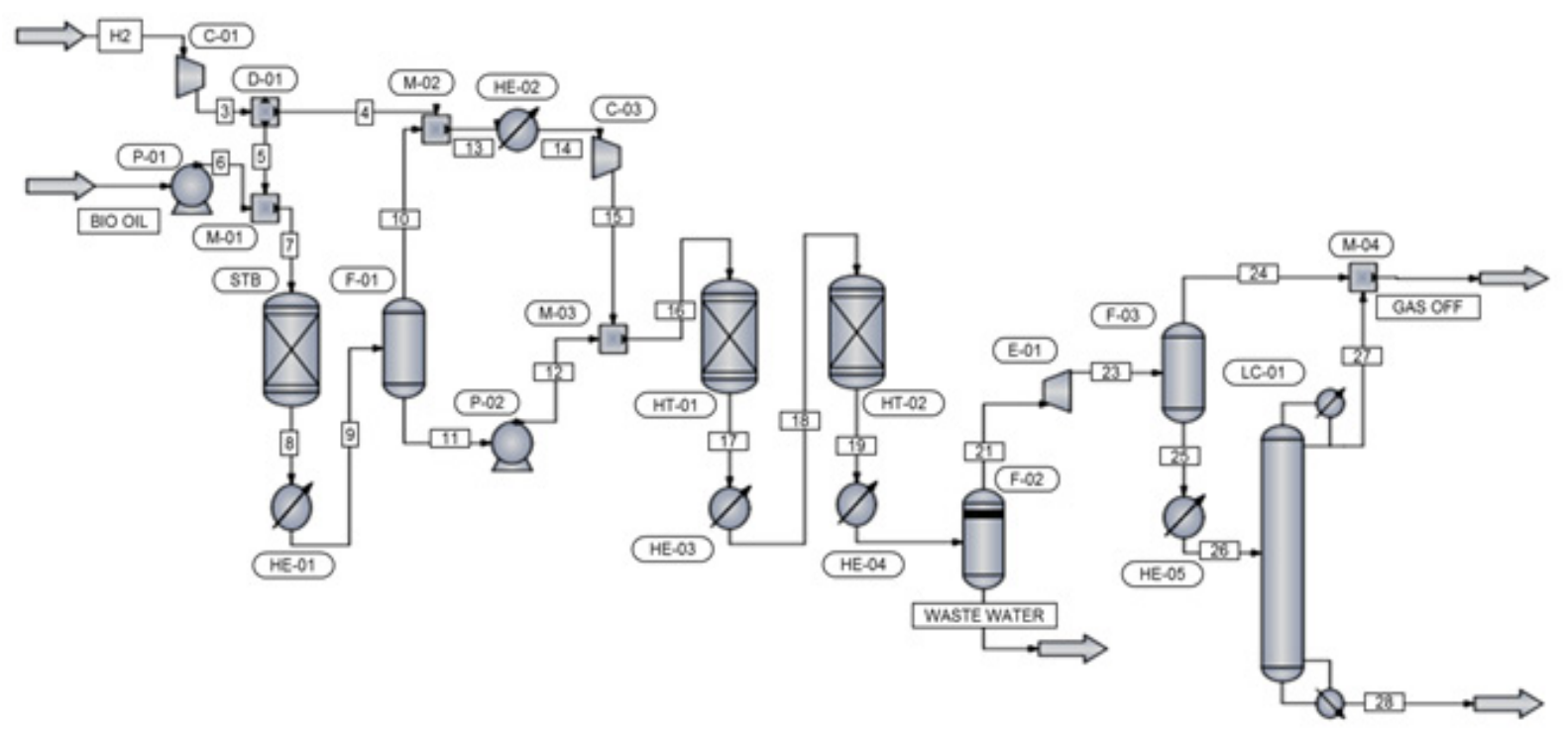

Figure 2 Overview process flow diagram for the conversion of bio-oil from into fuel.

three catalytic stages of hydrotreating (Jones 2013). Ruthenium based catalysts were employed at the first two reactor stages while at final stage molybdenum based catalyst was applied (Jones 2013).

The process was started by pumping bio-oil through $\mathrm{P}-01$ to raise it pressure to $81 \mathrm{~atm}$ and then sent it to the mixer M-01 to be mixed with hydrogen gases which the pressure had been raised to $81 \mathrm{~atm}$ by compressor $\mathrm{C}-01$. Then, this mixture sent to stabilizer or hydrotreating reactor stage 1 which operated at mild condition of $81 \mathrm{~atm}$ and $140{ }^{\circ} \mathrm{C}$. Products from stabilizer were cooled using heat exchanger HE-01 to temperature of $40{ }^{\circ} \mathrm{C}$ and then separated by flash drum F-01 to separate hydrogen gases from the products. Hydrogen gases from flash drum then mixed with fresh hydrogen in mixer $\mathrm{M}-02$. This hydrogen mixture was heated to $121^{\circ} \mathrm{C}$ with heat exchanger $\mathrm{HE}-02$ and pressurized to $136 \mathrm{~atm}$ using compressor C-02. Afterthat, the hydrogen mixed with the product from flash drum which already raised it pressure to 136 atm using pump $\mathrm{P}-02$ in mixer $\mathrm{M}-03$. This mixture then is sent to hydrotreater 1 or hydrotreating reactor stage 2. Hydrotreater 1 operates at 136 atm and $252{ }^{\circ} \mathrm{C}$. Products from hydrotreater 1 are heated to $288{ }^{\circ} \mathrm{C}$ and sent to hydrotreater 2 or hydrotreating reactor stage 3 . Hydrotreater 2 operates at $136 \mathrm{~atm}$ and $400{ }^{\circ} \mathrm{C}$. Products from hydrotreater 2 are cooled to $65^{\circ} \mathrm{C}$ with heat exchanger HE-04 to separate water from the upgrading oil products in flash drum F-02. From flash drum, the pressure of vapor phase upgrading oil products are lowered to 51 atm with expander E-01. Light gases then separated from upgrading oil products using flash drum F-03. Upgrading oil products were heated with heat exchanger HE-05 to $149^{\circ} \mathrm{C}$ and sent to light column separator to purify the oil.

The evaluation of the process design conducted by evaluating the overall mass balance, mass yield and energy yield with comparison to the similar studies by previous researcher.

\section{RESULTS AND DISCUSSION}

The mass balance of the simulation process is summarized in Table 5 that includes the material stream of bio-oil, hydrogen, waste water, upgraded oil and efluent that indicate balances between input stream and output stream. This table shows that the overall mass yield of 
Table 5 Mass balance of the bio-oil upgrading process

\begin{tabular}{lcr}
\hline Component & \multicolumn{1}{c}{ Input } & \multicolumn{1}{c}{ Output } \\
\hline & \multicolumn{2}{c}{$\left(\mathrm{kg} \mathrm{hour}^{-1}\right)$} \\
Bio-oil & 70352.57 & 0.00 \\
Hydrogen & 3857.80 & 3587.07 \\
Wastewater & 0.00 & 32081.36 \\
Upgraded oil & 0.00 & 22664.65 \\
Effluent gases & 0.00 & 15877.30 \\
\hline Total & 74210.37 & 74210.37 \\
\hline
\end{tabular}

the upgraded oil is $32.21 \%$ that calculated from the mass flow of upgraded oil at the output section divided by the mass flow of bio-oil at the input section. This result is higher compared to the study conducted by Wright et al. (2010) that produced overall yield of $12.6 \%$ (using cornstover as biomass resources) and Jones et al. (2013) that produced overall yield of $24.7 \%$ (using wood blended as biomass resources). However, hydrogen input into the process was absorbed only $7.02 \%$. To optimized the process efficiency, the remaining hydrogen released from should be recycle back into the process.

Energy efficiency to produce second generation biodiesel is calculated using the calorific values of the mass streams of the output compared to the calorific values of the mass streams of the input stream, using the next equation:

$$
\begin{aligned}
& \text { Energy Efficiency } \\
& =\frac{\text { Total mass output }(\mathrm{kg} / \mathrm{hour}) \times \text { Calorific value }(\mathrm{kcal} / \mathrm{kg})}{\text { Total mass input }(\mathrm{kg} / \mathrm{hour}) \times \text { Calorific value }(\mathrm{kcal} / \mathrm{kg})} \\
& \times 100 \%
\end{aligned}
$$

This model assumes 70.35 tons day ${ }^{-1}$ of bio-oil which has energy efficiency of $35.7 \%$. Energy efficiency is affected by the mass input and output, mass yield, as well as energy input and output. The value from this study is much lower than the study by Jones et al. (2013) that using bio-oil from wood chips but similar the the result from Wright et al. (2010) that applying bio-oil from corn stover. However,
Jones et al. (2013) mentioned that the utilization of biomass char as the energy source may increase the energy efficiency. Besides, the increase of mass yield can increase energy efficiency by increasing mass output of the product.

According to the process simulation, the upgrading process requires 76.5 MMJ hour $^{-1}$ of the energy, from the exothermic hydrotreating reactions. This value is higher compare to Wright et al. (2010) and Jones et al. (2013). The further optimization can be conducted by recycling hydrogen to reduce the energy for heating and incresing pressure of hydrogen.

On the other hand, the integrated fuel upgrading facilities could provide self-sustainable production facilities (Perkins et al. 2018). This model can be conducted by providing energy by combusting char from pyrolysis process. Therefore, further study is required by connecting the upgrading bio-oil facilities with the palm bio-oil production plant.

\section{CONCLUSION}

The process evaluation of upgrading bio-oil produced from palm EFB has been conducted. This work estimated the bio-fuel produced from palm residues collected from 19 units of a 60 tons hour ${ }^{-1}$ palm oil mill. The bio-oil input is 70.35 tons hours ${ }^{-1}$ with upgrading oil yield of $32.21 \%$.

Energy efficiency of this model is $35.7 \%$ while required $76.5 \mathrm{MMJ}^{\mathrm{M}}$ hour ${ }^{-1}$ of the energy. According to previous study, energy required for this process can be provided by using combustion of the pyrolysis char to supply energy for the pyrolysis as well as the upgrading process. Recycle process of hydrogen also required to reduce the energy consumption. Further study is required by connecting the upgrading biooil facilities with the palm bio-oil production plant. 


\section{ACKNOWLEDGEMENT}

This research was supported by The Ministry of Research, Technology and Higher Education of the Republic of Indonesia, under the "Sistem Inovasi Nasional" Incentive Program 2018.

\section{REFERENCES}

Abnisa F, Arami-Niya A, Wan DWMA, Sahu JN, Noor IM. 2013. Utilization of oil palm tree residues to produce biooil and bio-char via pyrolysis. Energ Convers Manage. 76:1073-1082. DOI: 10.1016/j.enconman.2013.08.038.

[BPS] Badan Pusat Statistik. 2018. Luas tanaman perkebunan menurut propinsi dan jenis tanaman, indonesia (000 Ha), 2011-2017 [online]. Available:https://www.bps.go.id/dyn amictable/2015/09/04/838/luas-tanaman-perkebunan-menurut-propinsi-dan-jenis-tanaman-indonesia-000-ha-2011-2017-.html. accessed 15 Dec 2018.

[BTG] Biomass Technology Group. 2017. Biomass technology group [online]. Available: http://www.btgworld.com/en/. accessed 10 Dec 2018.

[ESDM] Energi dan Sumber Daya Mineral. 2015. Peraturan Menteri no.12 tahun 2015 tentang perubahan ketiga atas peraturan menteri ESDM No. 32 Tahun 2008 tentang penyediaan, pemanfaatan, dan tata niaga bahan bakar nabati (biofuel) sebagai bahan bakar lain.

Fan L, Zhang Y, Liu S, Zhou N, Chen P, Cheng $Y$, Addy M, Lu Q, Omar MM, Liu Y, Wang Y. 2017. Bio-oil from fast pyrolysis of lignin: effects of process and upgrading parameters. Bioresour Technol. 241:1118-1126.

Garcia-Nunez JA, Rodriguez DT, Fontanilla CA, Ramirez NE, Lora
EES, Frear CS, Stockle C, Amonette J, Garcia-Perez M. 2016. Evaluation of alternatives for the evolution of palm oil mills into biorefineries. Biomass Bioenergy. 95:310-329.

Jones SB, Holladay JE, Valkenburg C, Stevens DJ, Walton CW, Kinchin C, Elliott DC, Czernik ES. 2013. Production of Gasoline and Diesel from Biomass Via Fast Pyrolysis, Hydrotreating and Hydrocracking: A Design Case, PNNL-18284. Alexandria (US): National Technical Information Service.

Perkins G, Bhaskar T, Konarova M. 2018. Process development status of fast pyrolysis technologies for the manufacture of renewable transport fuels from biomass. Renew Sust Energ Rev. 90:292-315.

Peryoga Y, Solikhah MD, Raksodewanto AA. 2014. Production cost assessment of palm empty fruit bunch conversion to bio-oil via fast pyrolysis. IJASEIT. 4(6):394-400.

Pradana YS, Daniyanto, Hartono M, Prasakti L, Budiman A. 2019. Effect of calcium and magnesium catalyst on pyrolysis kinetic of Indonesian sugarcane bagasse for biofuel production. Energy Procedia. 158:431-439. DOI: 10.1016/j.egypro.2019.01.128.

Shemfe MB, Gu S, Ranganathan P. 2015. Techno-economic performance analysis of biofuel production and miniature electric power generation from biomass fast pyrolysis and bio-oil upgrading. Fuel. 143:361-372.

Solikhah MD, Pratiwi FT, Heryana Y, Wimada AR, Karuana F, Raksodewanto AA, KismantoA. 2018. Characterization of bio-oil from fastpyrolysis of palm frond and empty fruit bunch. Mater Sci Eng. 349:012035. DOI: 10.1088/1757-899X/349/1/012035.

Surjosatyo A, Haq I, Dafiqurrohman $H$, Gibran FR. 2017. Effect of rice husk ash mass on sustainability pyrolysis 
zone of fixed bed downdraft gasifier with capacity of $10 \mathrm{~kg} \mathrm{hour}^{-1}$. AIP Conference Proceedings 1826. 020009 (2017). DOI: 10.1063/1.4979225.

[UN] United Nations. 2015. Ensure access to affordable, reliable, sustainable and modern energy [online]. Available: https://www.un.org/sustainabledevelopment/energy/. Accessed 15 Dec 2018.

Wright MM, Daugaard DE, Satrio JA, Brown RC. 2010. Techno-economic analysis of biomass fast pyrolysis to transportation fuels. Fuel. 89:S2-S10. 